\title{
KA MATE
}

\section{A commodity to trade or taonga to treasure?}

\author{
Jeremy Hapeta* \\ Farab Palmer ${ }^{\dagger}$ \\ Yusuke Kuroda ${ }^{\ddagger}$
}

\begin{abstract}
This paper advocates for change regarding commodification of Māori rituals in sport, arguing that haka are important taonga, symbolising Māori practices of knowledge transmission. Indigenous research methodologies based on Kaupapa Māori theory were utilised in this study. The literature reviewed highlights ongoing commodification of "Ka Mate" (a haka composed by Ngāti Toa chief Te Rauparaha) by transnational corporations in sport-related settings. A critique of promotional advertisements for sport events illustrates how recent legislation has had minimal impact. Further, it presents three examples, which coincided with the 2015 Rugby World Cup, of how corporate sponsors used haka for commercial purposes. This study includes pūrākau of three pūkenga immersed in te ao Māori, who suggest that haka, including "Ka Mate", should be treasured rather than traded by non-Māori, to ensure wellbeing of Māori and their taonga tuku iho. Conclusions provide recommendations for sport marketing researchers and practitioners alike.
\end{abstract}

* Ngāti Raukawa, Ngāti Huia, Ngāti Pareraukawa. Physical Education Lecturer, Physical Education Major Team Leader, School of Sport, Exercise and Nutrition, College of Health, Massey University, Palmerston North, New Zealand. Email: j.w.hapeta@massey.ac.nz

† Ngāti Maniapoto, Waikato. Senior Lecturer, School of Management, Massey University Business School, Palmerston North, New Zealand.

‡ Lecturer, School of Sport, Exercise and Nutrition, Massey University, Palmerston North, New Zealand.

DOI: 10.20507/MAlJournal.2018.7.2.5 


\section{Keywords}

haka, Kaupapa Māori, pūrākau, rugby, sponsorship

\section{Introduction}

Haka have many purposes and forms. One particular haka, "Ka Mate", composed by Ngāti Toa chief Te Rauparaha (Kāretu, 1993), has received global exposure, due mostly to being adopted as a pre-match ritual by the Aotearoa New Zealand national men's rugby team (the All Blacks). Increasingly, the All Blacks and "Ka Mate" have become symbols of New Zealand national identity and pride (Gardiner, 2007; Johnson, Martin, Palmer, Watson, \& Ramsey, 2013, 2014), but not without controversy and debate (see Bruce, 2013; Frankel, 2014; Jackson \& Hokowhitu, 2002; Sturm \& Lealand, 2012).

Kāretu (1993) argued that "performers [of haka] really do not appreciate what they are saying or why they are saying it, [and] greater cognisance has to be taken of the crucial role played by the language" (p. 86). Kāretu also suggested that "Ka Mate" had become "the most abused of all haka" (p. 65). A quarter of a century later, it appears that many still abuse "Ka Mate" and fail to fully understand its purpose. In essence, this paper seeks to address whether Indigenous knowledge forms such as haka are considered commodities for trade or taonga to treasure.

Aligned with concerns about appropriation and competing issues of meaning, this paper utilises qualitative and Kaupapa Māori (KM) approaches to critique how haka, especially "Ka Mate", are used for sport marketing purposes (Hoeber \& Shaw, 2017) and how this resonates (or not) with Indigenous perspectives. Indeed, through the inclusion of often "silenced" Indigenous voices in scholarship, this article acknowledges the value of pūrākau. The following sections outline the Indigenous methodologies used, the literature reviewed, exemplar cases analysed and implications discussed.

\section{Methodology}

Kaupapa Māori originally referred to a body of knowledge that has always been integral to the development of Māori epistemological and ontological constructions (Lee, 2009; Pihama, Tipene, \& Skipper, 2014). It refers to Māori-centred philosophies, frameworks and research practices, underpinned by principles including tino rangatiratanga (Lee, 2009; G. H. Smith, 2000). Kaupapa Māori theory (KMT) is also about developing a critique of Pākehā systems and is broadly described as research by Māori (although not exclusively), with Māori and for Māori (G. H. Smith, 2000) to pursue self-determination in all aspects of knowledge creation and application.

Keeping this aspiration for tino rangatiratanga in mind, this study adopted $\mathrm{KM}$ conventions. The primary author has Ngāti Toa whakapapa and consent (by Māori), the research includes pūrākau of Māori pūkenga (with Māori), and the critique of literature, legislation and practices reaffirmed the mana of mātauranga Māori (for Māori).

\section{Mātauranga Māori ways of knowing}

Mātauranga Māori was created from the worldview that Māori descend from Papatuānuku and Ranginui, and reside in Te Ao Mārama (Pihama \& Southey, 2015). This philosophical perspective is passed from generation to generation through pūrākau incorporated into rituals such as haka (G. H. Smith, 2000). Takiwairua Marsden suggested that, as a result, mātauranga Māori often "remains invisible to [Māori]" (as 
quoted in Royal, 1998, p. 85). This, combined with ongoing marginalisation of Indigenous peoples' knowledge systems through Western research practices, has maintained and perpetuated key elements of colonisation in research (L. T. Smith, 1999).

Conducting KM research can enhance a stronger sense of cultural identity (Auger, 2016; Cram, 2014; Durie, 2003; Muriwai, Houkamau, \& Sibley, 2015) that benefits Indigenous communities. How mātauranga Māori interacts with other ideologies and disciplines of knowledge privileged in scholarship (Hoeber \& Shaw, 2017; Pihama \& Southey, 2015) also creates an opportunity for new understandings and action. The use of pūrākau (as told through haka and by pūkenga) therefore provides a means of analysing the "space" between mātauranga Māori and dominant sport marketing practices.

\section{Pūrākau}

Passing on mātauranga Māori through pūrākau, core messages within Māori stories, is a traditional and valid pedagogical process that should be protected and understood as an anthology of knowledge still relevant today (Lee, 2009; Pihama et al., 2014; Pihama \& Southey, 2015). The use of purrākau as a research strategy that is similar to narrative inquiry (Lee, 2009) honours oral traditions and is utilised here to highlight key messages in Indigenous forms of expression, including haka.

Haka can be used for celebrations, protests, acknowledgement and identity that may align with nationality (New Zealander), ethnicity (Māori), subculture (e.g., sport), a movement (e.g., Māori sovereignty) or a brand (see Gardiner, 2007). The benefits of pūrākau embedded within ngā taonga tuku iho such as haka, however, tend to be absent in sport marketing research.

This paper presents pūrākau in regard to haka in general and "Ka Mate" in particular: firstly, from the perspective of pūkenga knowledgeable in mātauranga Māori who are also rangatira from iwi closely associated with "Ka Mate" (i.e., Ngāti Toa, Ngāti Raukawa and Ngāti Tūwharetoa/Ngāti Porou); secondly, by critically reviewing literature and legislation from a KMT perspective; and thirdly, by including parts of the pūrākau from pūkenga who responded to exemplar expressions of haka in sport marketing platforms.

This involved kanohi ki te kanohi kōrerorero with three pūkenga (purposively selected for their expertise in mātauranga-a-Ngāti Toa and mātauranga Māori in relation to haka), from Ngāti Toa, Ngāti Raukawa and Ngāti Tūwharetoa/Ngāti Porou. The kōrerorero opened with whakawhanaungatanga, ranging between one and a half to four hours in length, and were guided by open-ended questions related to (a) how mātauranga of haka (including "Ka Mate") were handed on to them, (b) how Māori and wider New Zealand society are passing on haka today, (c) how they wanted it handed on to future generations and (d) the use of haka in sport marketing.

Once transcribed, the pūrākau were member checked by the pūkenga, and they are presented here as authentically as possible (Stride, Fitzgerald, \& Allison, 2017).

\section{Mātauranga Māori: Pūkenga pūrākau}

The following initial excerpts demonstrate the importance of haka to mātauranga Māori. In this pūrākau, the Ngāti Toa pūkenga expressed the Māori philosophy of matua rau-it takes a village to raise a child-highlighting that traditional pedagogical approaches often included haka:

My children have been immersed in Ngāti Toatanga. Through regular cultural activities and events, including the haka, since their early years. Not just taught by me, but it has been an integral part of their growing up at hui-a-iwi, marae and rūnanga hui, wānanga, kapa haka, waka ama. 
The Ngāti Raukawa pūkenga also explained the mātauranga and emotional response of his first embodied experience of "Ka Mate":

[The All Blacks] came to North America ... in 1972-1973 and we went to watch the game [vs British Columbia, Vancouver, 19 October 1972]. Our father told us that when he got up to do the haka ... to get up with him. When you are 9-10 years old you just don't do that ... our father must have taught us "Ka Mate" because the haka performed that day was "Ka Mate" ... away they went. And up jumped our father in the middle of the stands, doing "Ka Mate" and he is looking at us. I was sitting there going, who is this strange man? We weren't going to get up . . . everybody was looking towards us ... our father did a solo performance ... I'm here with my mother, I don't know who that man is ... It's all right to do it at home, but not publicly in a strange place in front of a whole lot of strangers ... it was quite a vigorous performance. I never asked my father, but on reflection it was probably a combination of a lot of pride [as Māori in Canada] and a bit of a tangi for home.

This experience of mātauranga Māori for him as a child was precious and powerful, and expresses how expectations of appropriate behaviour can differ depending on cultural contexts and age or wisdom of the performers or observers. There is also a suggestion that although their father taught them the " $\mathrm{Ka}$ Mate" words and actions, the nuanced meaning associated with it was less evident at the time.

Reflecting upon his haka development, the Ngāti Tūwharetoa/Ngāti Porou pūkenga shared a purrākau of the values and messages instilled in a specific haka:

I am forever grateful to those guys, who didn't have the best tuition technique, but were actually handing on the haka ... "Mangumangu Taipo: E kore taka te ingoa Māori i runga i a koe. He mangumangu taipo nei hoki tātou, pākia! Te kupu a Tohu ki ngā iwi, e rua. E kore piri te uku ki te rino ka whitingia e te ra ka ngahoro". I love that haka because of what it says: "whatever is heaped upon you, through the duration of your life, when the sun shines, your true self will be revealed" ... it means you need to strengthen your backbone . . . be resilient, because life will throw many things at you! But if you're strong in your spirit and your hinengaro, your tinana, your whānau is strong, all of these things that Tā Mason [Sir Mason Durie] has said to us, if you're strong in all those areas you can endure all of these things and that to me was encapsulated in that particular haka.

The purpose of that haka ("Mangumangu Taipo") was to pass on key messages about resilience and perseverance. Pūrākau were deliberately embedded into the lyrics, as Kāretu (1993) had emphasised, and these were passed on to students through haka as lessons (on resilience and perseverance) regarding how to thrive as Māori in modern society.

Following the use of partial segments of pūrākau in this section to highlight the importance haka and mātauranga Māori have within te ao Māori, the next section applies a KM lens to review literature and legislation related to haka and "Ka Mate".

\section{Literature and legislation}

Academics suggest that sport scholarship lacks the innovation required to have meaning for specific communities (Sparkes, 1995; Stride et al., 2017). Hence, few studies in sport marketing have had an impact at the level where sponsorship decisions are made, and even fewer have examined the impact on Indigenous communities or utilised their research methodologies (Hoeber \& Shaw, 2017). This suggests that a $\mathrm{KM}$ analysis of haka in sport marketing may provide innovation in sport scholarship.

Haka, especially "Ka Mate”, have been 
associated with global brands and corporations aligned with rugby teams and events, such as Heineken, Adidas and the American International Group. This review, therefore, explores sport marketing scholarship focusing on "Ka Mate" and the All Blacks (Jackson, Batty, \& Scherer, 2001; Jackson \& Hokowhitu, 2002), alongside contemporary use (and arguably misuse) of "Ka Mate" by transnational agencies and sponsors (Frankel, 2014; Grainger, Newman, \& Andrews, 2005; Jackson \& Andrews, 2005; Sturm \& Lealand, 2012).

In the early 1990s, McKay and Miller (1991) were trailblazers in illuminating the link between sport branding and national identity "down under" when they highlighted that increasing commodification of Australian sports by multinational corporates was a potential threat to national identity:

New Zealand Breweries has attempted to increase awareness of its premier beer, Steinlager, by sponsoring Rugby Union and yachting ... The international, and in the corporate sense multi-national, nature of Australian sport is illustrated ... when ... the Queensland minister for sport stated ... he did not want Queenslanders subsidizing New Zealand's All Black Rugby Union team or its bid for the America's Cup. (p. 91)

Shortly after the 1999 Rugby World Cup (RWC) campaign, Jackson et al. (2001) examined global and local debates with a focus on sport (rugby) and the corporatisation of national identity. Jackson et al. (2001) highlighted how Adidas used "Ka Mate" to "localise" and embed itself into the New Zealand market while using the All Blacks as part of their global marketing campaign. They also mentioned the resistance encountered from groups, including Ngāti Toa, who claimed Adidas exploited "Ka Mate" and Māori culture (Reid, 2000). Jackson et al. (2001) recommended that to avoid possible future disjuncture, global sport marketers should create clear processes and procedures when entering "local" markets to understand cultural values and traditions. Subsequently, Jackson and Hokowhitu (2002) provided an example of cultural resistance towards the corporatisation of New Zealand identity revealed in a Māori intellectual property rights (IPR) lawsuit that unsuccessfully challenged Adidas using "Ka Mate". The lack of success seemed to suggest that:

the [IPR] system is totally inadequate to recognise and protect Māori cultural values and cultural rights ... the system was developed to protect private economic rights ... when you talk about Māori tanga cultural heritage rights, these are collective by nature ... they don't belong to one individual; they belong to the whanau, the hapu, or the iwi. (Harcourt, 2000, as quoted in Jackson \& Hokowhitu, 2002, p. 135-136)

Numerous Māori scholars (e.g., Muriwai et al., 2015) reinforce that Māori rights are collective. Jackson and Hokowhitu (2002) highlighted the problems Ngāti Toa faced in protecting cultural spaces where Indigenous identities are constructed, acknowledging that cultural commodification was and is a challenge many Indigenous peoples experience worldwide (Auger, 2016; Durie, 2003). They warned that while new media technologies can advocate for social change, they can dually be avenues of exploitation or eradication of Indigenous interests.

Scholars Sturm and Lealand (2012), for example, explored local and global media mechanisms used to evoke New Zealand nationalism during the New Zealand hosted 2011 RWC. They suggested that from the announcement that New Zealand would host the tournament, "it was clear [that] this event was not just about a series of games ... [it] was as much about financial returns, visitor numbers and showcasing New Zealand to the rest of the world" (p. 46). Indeed, they argued that powerful, contemporary and deliberate strategies and media technologies created: 
"imagined communities", whereby these myths, images, discourses and narratives reconfirm a "shared" sense of national identity and unity [along with] the occasional embracing of Maori culture. (Sturm \& Lealand, 2012, p. 48)

Global media often achieve these imagined communities by "very fast cutting" (Horne, Tomlinson, Whannel, \& Woodward, 2012, p. 87), saturation, symbolic construction and representation where pre-coded myths are deliberately embedded into advertising campaigns. Sturm and Lealand (2012) also argued that RWC 2011 met the interests of a powerful few:

[The] New Zealand government who had poured millions into the RWC . . the IRB [International Rugby Board] who endorsed its (inter)national appeal for global audiences to increase their revenue streams; the sponsorship of transnational corporations . . . and the NZRU [New Zealand Rugby Union] carefully managing the national team with a view to expanding the reach of the All Blacks "brand". (p. 51)

Frankel (2014) suggested that corporates Ford, Lego, Sony and Fiat had all extracted value from Māori culture to sell their products. She also discussed the boundaries of protection around traditional knowledge, using "Ka Mate" to illuminate the commodification of cultural property and IPR in the public domain. Frankel (2014) considered haka performance art, but suggested that descendants of Te Rauparaha, who have legally fought to gain rights over its use, were unsuccessful in trademark registration because "the intellectual property system was not designed to protect traditional knowledge" (p. 2). Change eventually came, according to Frankel, in the form of a Waitangi Tribunal claim in October 2011.

The Ko Aotearoa Ténei Ministry of Justice report (Waitangi Tribunal, 2011) describes the 262nd claim, lodged to the Waitangi Tribunal in October 1991, as one of the most complex claims ever lodged. Commonly referred to as "WAI 262", it involved claims in regard to the Indigenous flora and fauna and Māori cultural intellectual property. It is within the WAI 262 claim that Ngāti Toa sought to cease the exploitation and regain some control over "Ka Mate" (Frankel, 2014).

Essentially, WAI 262 extends beyond the relationship between pā and Parliament and therefore affects all New Zealanders (Frankel, 2014). The claim explains key themes of the six claimants' concerns, the Crown's responses to these and the main recommendations made (Waitangi Tribunal, 2011). Fundamentally, claimants sought to protect Māori culture and identity. Their concerns were that existing policies allowed, among a myriad of examples, "Ka Mate" to be used in foreign television advertisements by corporate companies that used traditional knowledge about taonga tuku iho without acknowledgement or in some cases consent (Waitangi Tribunal, 2011). The WAI 262 report concluded that (a) "Māori are entitled to prevent offensive and derogatory uses" of their taonga (both tangible and intangible); (b) Kaitiaki obligated to oversee the use of taonga have "the right to be consulted and, where appropriate, to give consent to the commercial use of such works" and (c) Māori are "entitled to prevent offensive and derogatory public uses of mātauranga Māori” (Waitangi Tribunal, 2011, p. 48).

Findings and recommendations from WAI 262 set a precedent, and it was closely followed by the Haka Ka Mate Attribution Act (henceforth, "the Act"; Ministry of Business, Innovation \& Employment [MBIE], 2014). Eventually, after a process that began in 2012 (post the RWC, 2011), the New Zealand Government acknowledged the importance of "Ka Mate" to Ngāti Toa and passed legislation requiring attribution to $\mathrm{Ngāti} \mathrm{Toa,} \mathrm{including} \mathrm{in}$ commercial uses, of "Ka Mate". In line with WAI 262, the Act (MBIE, 2014) states: 
1. Ngāti Toa have a right of attribution in relation to Ka Mate.

2. The right of attribution applies to (a) any publication of "Ka Mate" for commercial purposes, (b) any communication of "Ka Mate" to the public (local or global) and (c) any film including "Ka Mate" shown in public or issued to them.

3. Anything to which the right of attribution applies must include a statement that Ngāti Toa Chief Te Rauparaha composed Ka Mate.

4. The statement must be: (a) clear and reasonably prominent; and (b) likely to bring the identity of Te Rauparaha, as the composer of Ka Mate and a chief of the Ngāti Toa tribe, to the attention of the audience (viewers or listeners).

5. However, the right of attribution is subject to any written waiver given, or written agreement entered into, by the rights' representative (Ngāti Toa).

However, it is important to note that the Act is New Zealand based legislation and does not apply offshore. Despite ongoing discussion since the 1990s at the World Intellectual Property Office regarding an international treaty for the recognition of traditional knowledge and cultural expressions, progress has been slow (Tuffery-Huria, 2016). Mindful of the Act's intent, the following section provides a critical contextual analysis of three exemplar cases where "Ka Mate" has recently been used in sport marketing platforms.

\section{Exemplar cases}

Thus far, this paper has considered the haka in relation to mātauranga Māori and literature preceding the Act. Attention now turns to the critical textual analysis, from a KM perspective, of three mediated haka representations publicly disseminated post the Act, prior to and following the 2015 RWC: (a) Jacomo's
“Hakarena” campaign, (b) Heineken's "Fight or Flight" competition and (c) tennis star Caroline Wozniaki's haka lesson.

\section{Jacomo's "Hakarena" campaign}

In a pre-tournament RWC 2015 promotion, former English rugby captain and 2003 RWC winner Matt Dawson featured, along with several support actors, in an online video for United Kingdom clothing company Jacomo that parodied Ka Mate. They blended music and moves from the hit Spanish dance song "Macarena" by Los del Río (1993) with "Ka Mate" lyrics and gestures to create a "hybrid" dance called the "Hakarena". This campaign began with eight seconds of subliminal fast cutting (Horne et al., 2012), then Dawson stated:

[I]t's the world's biggest rugby event and it's on home soil. England have an amazing chance to be crowned world champions for just the second time in history. But, there is a major obstacle-the All Blacks ... with awesome power, strength, depth and one secret weapon - the haka. They are using it to intimidate us ... [but] we've got our own secret weapon ... Ka mate, ka mate [background lyrics]. ("Hakarena”, 2015)

Then, several actors performed the "Hakarena", in which, for example, a slap of the chest associated with haka had become a chest caress. At the time, Ngāti Toa Executive Director Sir Matiu Rei stated, "this video is disrespectful and belittling to our cultural performance, the All Blacks and Māori people ... I feel for New Zealanders, not just Māori, I feel sorry for anyone who has to watch it" (as quoted in Te Kanawa, 2015). This public expression of indignation by Sir Matiu Rei demonstrated that Ngāti Toa see "Ka Mate" as a taonga to be treated respectfully, not as a commodity to be belittled in order to promote a brand and sporting event. 


\section{Heineken's "Fight or Flight" competition}

The 2015 RWC, hosted by England, enlisted Heineken as a major sponsor. Heineken's activation strategy commissioned a media agency to create a competition for customers set in a Dublin bottle store. A promotional video capturing the tournament's progress depicted unsuspecting customers flipping a coin for a chance to win free tickets to the RWC final. Upon the outcome, customers were informed, "Well done. Now for your next challenge ...", and were immediately surprised by three "Māori" actors who leapt out and performed a generic haka. At the conclusion, the actors challenged customers to perform their best haka for a chance to win the free RWC tickets. In challenging customers, the actors performed a haka. However, want-to-be "winners" responded with amateur performances of "Ka Mate".

While Heineken may argue that they had no control over which haka the participants responded with, they did control the renditions publicly distributed online to consumers, and they could have respectfully taken, at the least, steps to acknowledge Ngāti Toa. Indeed, such "behind the scenes" editing decisions highlight a limitation of how the Act can be considered and enforced when dealing with global companies unbounded by national borders and legislation.

Furthermore, New Zealand media journalist Kenny (2015) stated that Heineken was "the latest company to rip off the haka for advertising" (para. 1). Former politician and Māori Party co-leader Sir Pita Sharples also labelled this advertising strategy "shameful and insulting" (as quoted in Kenny, 2015, para. 7) to Māori and wider New Zealand society. This suggests that attributing "Ka Mate" to Ngāti Toa is not enough. WAI 262 (Waitangi Tribunal, 2011) goes a step further and insists Māori are entitled to prevent offensive and derogatory uses of taonga and mātauranga Māori.

In any case, the unsuspecting shoppers performed "Ka Mate" while judges and other shoppers watched on in amusement in a Heineken-saturated bottle store, highlighting that this production was the manifestation of a transnational marketing strategy. Whether intentional or not, the use of any haka for commercial purposes, performed with little understanding of the nuances and meanings of this cultural ritual, and distributed to the public without appropriate acknowledgement, disrespects the intended spirit of WAI 262 and the Act.

\section{Wozniaki's haka lesson}

The most recent example of strategic haka use by sport sponsors was at the 2016 International Tennis Tournament in New Zealand. Organisers of the newly named ASB Classic secured several high-profile, 2015-RWC-winning All Blacks who provided top international women's tennis star Caroline Wozniaki with a "personal haka lesson" (Mabire, 2016). This story was covered by national media, appearing on the national primetime news bulletin.

It is important to note that from a mātauranga Māori perspective, movements and gestures in haka can be gendered. Many haka include facial movements, such as pūkana and ngangahu performed by men and women, whētero traditionally performed by men and pōtete usually performed by women. In the televised footage Ms Wozniaki was instructed on the words and actions of "Ka Mate" and encouraged to "poke out your tongue" (whētero), a practice inconsistent with tikanga Māori (Mead, 2016) because wāhine do not normally protrude their tongue owing to the symbolism of this gesture (i.e., an extension of male genitalia). This scenario demonstrated an example of corporate sponsors dislocating a distinctive local ritual from its cultural meaning. Despite this display occurring in New Zealand, where the 2014 Act applies, there was no verbal or written attribution to Ngāti Toa or Te Rauparaha in the news story. 
To date, few studies have considered the impact that appropriation of haka has on the lived experiences and wellbeing of Māori, and of Ngāti Toa. This paper contributes to the ongoing dialogue by privileging the voices of pükenga, thus bringing this analysis back to a mātauranga Māori perspective.

\section{Pūkenga discussion}

To understand the impact that use of "Ka Mate" (and haka generally) for commercial purposes has had on the mana and sense of wellbeing of Māori communities, key pūkenga were asked to share their responses to videos of the aforementioned marketing campaigns. The Ngāti Toa pūkenga seemed most deeply affected. He expressed passion for passing mātauranga Māori to his children, grandchildren and future generations in culturally appropriate ways. His response reflected the intent of WAI 262 and the Act, and acknowledges Ngāti Toa as kaitiaki who "gifted" "Ka Mate" to the world.

His wero calls for others to perform it with respect, as the continuity of traditional rituals becomes increasingly valued but still threatened in contemporary Māori and New Zealand society (Kuroda, Geisler, Morel, \& Hapeta, 2017; Muriwai et al., 2015). Kuroda et al. (2017) and Muriwai et al. (2015), for instance, posit that strong cultural roots and a secure cultural identity are central to holistic wellbeing, and that the respectful treatment of taonga tuku iho such as haka plays a role in this. This pükenga believed, however, that the exemplar global media strategies presented to him as part of this study undermine the wellbeing that Māori could gain from seeing their taonga on the world stage: "The commercialisation of Māoritanga, including the haka, in that way ['Hakarena'] is abhorrent and manifestly unjust and is in need of a watchdog to monitor these and further developments."

Indeed, this pūkenga was aware of the kind of revenue generated for brands associated with mega-sporting events such as the RWC. Heineken, for instance, recompensed their investment in 2015 RWC sponsorship with sales soaring by $4.5 \%$ (Gunsorknives, 2016). This Ngāti Toa pūkenga added:

Heineken's motive is clear, to recoup their huge investment as a [RWC] sponsor . . . they do that by making heaps of money through beer sales, by offering the public a distinctive advertising and marketing formula that pokes fun-not admiration or reverence-towards New Zealand's Indigenous culture and Ngāti Toa's haka without knowing the background or context.

In terms of Heineken's "Fight or Flight" competition, the Ngāti Raukawa pūkenga discussed concerns about the way in which the advert had been filmed, edited, produced and publicly distributed:

It's ["Ka Mate"] certainly something that is known throughout the world, [but] obviously not very well looked after. I have no ill will against the individuals ... performing something that they have seen or heard that has captured their curiosities, to the extent that they know a little bit about how to perform it, what we [Māori, Ngāti Toa] might say out of ignorance ... but it's the deliberate set-up that is really disappointing. I think Heineken can't plead ignorance.

Finally, in a commentary regarding the haka lesson at the ASB Classic involving several highprofile All Blacks and Caroline Wozniaki, the Ngāti Toa pūkenga said:

New Zealand Rugby makes a lot of money off Māori and the haka. They knowingly allow this to occur ... they [New Zealand Rugby (NZR)] could provide improved guidelines to sponsors to ensure that the commercialisation of the haka is done in a culturally appropriate way. NZR's relationship with Ngāti Toa should be based on respect for the haka. 


\section{Present practices}

Collectively, the pūkenga concurred that the current All Blacks do a far better job with tikanga and performing "Ka Mate" compared with past renditions by previous generations. Previously, it was perceived to be "a non-event at the time ... it wasn't done very well" (Andy Haden, as quoted in Johnson et al., 2014, p. 106). Indeed, Sir Graham Henry (ex-All Black Coach, 2004-2011) stated that haka performed by the modern All Blacks are "very meaningful and a lot of work's gone into it . . they [players] take performing haka and understanding the meaning of them particularly seriously ... it's a part of our legacy, a very important part of New Zealand culture" (in Johnson, 2014, p. 207). The Ngāti Raukawa pūkenga agreed that "Ka Mate" is now given greater respect:

I remember [prominent Ngāti Toa pūkenga] described the haka as a "Taonga ki te ao", a Gift to the world ... that's probably shared by most of Ngāti Toa. It's nice to see that it's given due regard ... being cared for in that way. In the way that they [current All Blacks] perform it ... I think there is an element of pride there. People have been given good instruction, Māori, Pākehā, Pacific Islander.

This aligned with a statement by another Ngāti Toa member that was quoted in the New York Times: "The All Blacks perform it fantastically. It's just when it starts selling the All Blacks brand and all the other sponsors that go along with it, that we want to have a talk to them about it" (Wi Neera, 2009).

The importance that the pre-game haka has for the current Māori All Blacks Team (MAB) was also underscored by the Ngāti Tūwharetoa/ Ngāti Porou pūkenga:

The haka is the most unifying apparatus or implement that we have in the team that drags and pulls them together ... you have to practise it . . a all day, every day . . . in the lifts, in your rooms, tuakana, teina. Where one goes, we all go. If someone's struggling, hop on, he waka eke noa, help them ... it's serious. You can joke around with different things, but this [haka] is serious ... the most unifying mechanism ... we have in our tool kit.

This pūkenga also highlighted how respect for the haka has helped with public relations and sponsor relationships:

There is a lot of interest in the haka, when we $[\mathrm{MAB}]$ go places. Everyone wants to "throw peanuts at the monkeys" ... get them to perform. We [MAB management] do some stuff around that ... if it is tikanga based, we perform the haka. If I speak and we need tautoko we could do a haka, but most of the time we sing a waiata . . . but if not I will turn it around ... teach them a song and get them to perform.

When quizzed further to elaborate on the perceived impact that corporate sponsors and global mega-events have on Māori communities, this pūkenga said:

people are treating it [haka] with disrespect ... I go home sometimes and the old people come down and visit me when I'm on holiday and they say, "there are things not right here". When I see people doing things, I can't do anything, with regards to the denigration of the things we hold tapu, dear and close to us ... except continue to show disdain where I have the opportunity. If I'm on a public platform ... say we don't take kindly to that. Also, to just do it right ... showing people that this is actually special to us.

This suggests that the global misuse and appropriation of cultural taonga such as haka negatively affects the wellbeing of Indigenous populations. Despite exasperation with the status quo, the pūkenga involved sharing their pūrākau aspired unanimously for better 
treatment of Māori culture and taonga in the future.

\section{Passing on haka to future generations}

Pūrākau are effective for passing on mātauranga Māori and wellbeing through various forms, including haka. This is expressed by the Ngāti Toa pükenga who suggested that haka is best learned in "the same way as my kids, through regular involvement and engagement at Ngāti Toa and other cultural activities alongside their whānau, hapū, iwi and taught by their peers, rangatahi, as well as their pūkenga, kuia".

The desire to see traditional rites of passage continue and thrive in a context that is imbued with mātauranga Māori is apparent in the pūrākau of this pūkenga. Nonetheless, the Ngāti Raukawa pūkenga suggested that when taonga are taken out of a Māori context:

pressure needs to be put on [the] NZR to address it . . . that's the level that the discussion needs to be at. They need to have a discussion with Ngāti Toa about it. Be interesting to see what their [Ngāti Toa's] response is?

\section{Conclusions}

As demonstrated, Heineken, Jacomo and ASB are not the first corporates to use the haka for commercial purposes. If history continues, and the rights and concerns of Māori and iwi (such as Ngāti Toa) are ignored, the commodification and misappropriation of taonga will continue unabated. Sponsorship plays a key role in sustaining sporting organisations such as NZR in the professional era (NZR, 2016). Similarly, "Ka Mate" plays a major role in presenting a particular narrative about New Zealand's national identity and race relations, especially in the domain of sport and rugby. "Ka Mate" has also been repackaged by transnational corporations to create global brands that are locally connected, relevant, nostalgic, exotic and imbued with certain values associated with sport and Indigenous cultures. Unfortunately, WAI 262, the Act and past scholarly critiques have not had much impact regarding how it is used, attributed or expressed, even when performed in New Zealand where the Act should be applied.

Nonetheless, a "pūrākau approach can challenge dominant discourses that continue to decenter our experiences, cultural notions and aspirations in ways that resonate and connect to our people" (Lee, 2005, p. 13). It is necessary, therefore, to include Māori and Indigenous voices, realities, stories and epistemologies in the IPR and marketing debate, ensuring that these perspectives are not excluded from important dialogue and decision-making.

The ritual of haka as a form of pūrākau has created international awareness of this Indigenous form of knowledge. Perhaps including more Indigenous pūrākau in sport marketing scholarship will create greater awareness of Indigenous rights and concerns regarding respect of taonga. The debate about whether haka should be used as a commodity to trade or taonga to treasure is ongoing, but the use of pūrākau in scholarly and organisational debates should be encouraged to make progress in this dialogue space, perhaps moving from an "either—or" to an "and—and" conversation.

In the meantime, this paper has illustrated how global corporations connected with sport continue to sidestep issues of cultural exploitation and misappropriation of the haka by subtly using editing techniques and mediated expressions of this Indigenous ritual to avoid breaches of IPR and specifically the Act, which requires that the haka be attributed to Ngāti Toa, but is only applicable in New Zealand. As a result, they dislocate taonga tuku iho from whakapapa to benefit their brands, irrespective of the impact their appropriation has on the overall wellbeing of Māori. Perhaps they are simply not aware of the Act and the wider implications for Indigenous wellbeing when taonga are not treasured. 
The pūrākau of pūkenga, which opened and closed this analysis from a KM perspective, recognises how much traditional forms of identity expression and knowledge dissemination are cherished, and how deep the impact that the appropriation of "Ka Mate" has on the wellbeing of their communities and mātauranga Māori generally. So, in closing we ask, is it acceptable for corporations to appropriate cultural taonga for the purposes of global trade? The pükenga suggested it is time for key players (Ngāti Toa, Māori, NZR) to e tū:

Ngāti Toa should be more forthright in analysing and monitoring the responsiveness of NZR to ensuring the haka is conducted in a way that is respectful, and consistent with sponsors' contractual obligations. Ngāti Toa needs to be more interested in maintaining the mana of the haka, safeguarding its reputation as the owner of the haka ... the public, especially Māori, need to be vigilant ... to not accept untoward commercialisation of Indigenous cultural icons such as the haka.

Or, as Olsen (2015) suggested, just "as Te Rauparaha did in 1820, New Zealand needs to step from the darkness and into the sunlight in its approach to protecting the culture of its Indigenous peoples" (p. 59). It is time sport organisations, event managers, media and sponsors aligned with Māori, WAI 262, legislation (the Act) and Ngāti Toa aspirations to ensure that these treasures are represented in culturally responsive and appropriate ways. As a major organisation in New Zealand's sporting landscape, NZR could play a lead role in guiding global corporations and sponsors in relation to access to and appropriate use and attribution of haka. We can no longer turn a culturally blind eye (Hippolite \& Bruce, 2014) to disrespectful ways the haka is re-presented and repackaged for commercial purposes. NZR appear to be responding to this karanga with the establishment of a kaitiaki group for haka within the All Blacks, a pūkenga for the Māori All Blacks, the adoption of a Respect and Inclusion programme in 2017, a cultural subcommittee of the New Zealand Māori Rugby Board, and the appointment of a Māori cultural advisor in 2018. Time and KM analyses will tell whether these formalised roles and strategies can turn the tide with regard to misappropriation and exploitation of taonga in sport marketing strategies by global brands. In closing, this paper ends with the wero of a Māori Television reporter to put an end to belittling the mana of the haka and thus Ngāti Toa Rangatira: "Engari e manako ana ko Ngāti Toa Rangatira ka whai māramatanga te Ao, kia kaua e whakaiti te mana o te haka" (Te Kanawa, 2015).

\section{Glossary}

Aotearoa
e tū
haka
hapū

he waka eke noa

hinengaro

hui

iwi

kaitiaki

ka mate

Ka Mate

kanohi ki te kanohi kapa haka

karanga

kaupapa

Kaupapa Māori

\author{
New Zealand \\ to stand/take a stance \\ dance-like movement \\ sequence \\ a subtribe of an iwi; \\ pregnant \\ we are all in this \\ together \\ mental, emotion; \\ thoughts, feelings \\ meeting, discussion \\ (interview) \\ an extended \\ population of \\ people \\ custodian, guardian \\ I will die \\ the name of the \\ Ngāti Toa haka \\ face to face \\ group performing \\ arts or culture \\ display \\ call, summon \\ purpose \\ a distinctive Māori \\ research paradigm
}




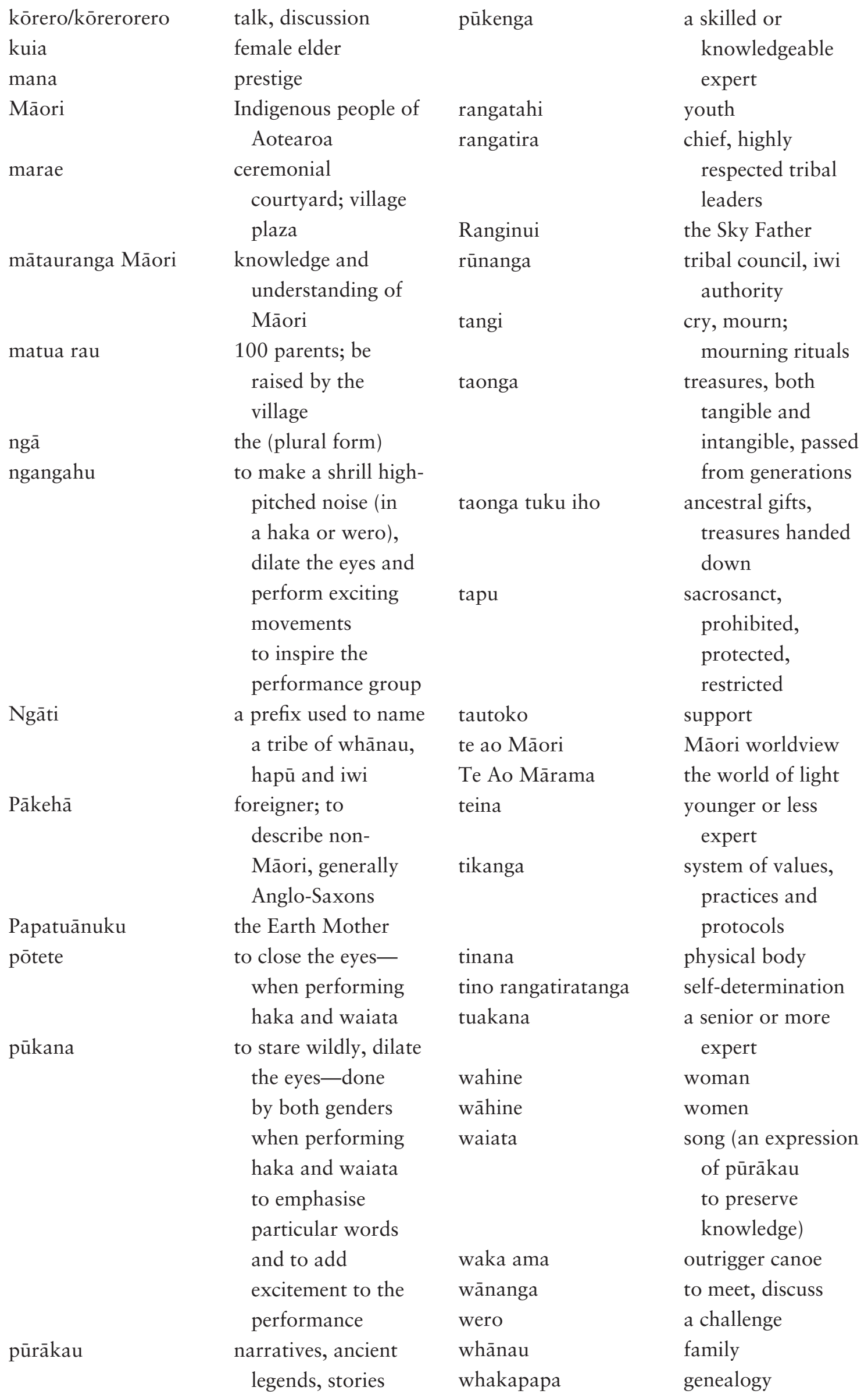



whakawhanaungatanga establishing relationships
whētero

\section{References}

Auger, M. (2016). Cultural continuity as a determinant of Indigenous Peoples' health: A meta-synthesis of qualitative research in Canada and the United States. International Indigenous Policy Journal, 7(4), 1-24. http://doi.org/cvb3

Bruce, T. (2013). (Not) a stadium of four million: Speaking back to dominant discourses of the Rugby World Cup in New Zealand. Sport in Society, 16(7), 899-911. http://doi.org/cvb4

Cram, F. (2014). Measuring whānau wellbeing: A commentary. MAI Journal: A New Zealand Journal of Indigenous Scholarship, 3(1), 18-32.

Durie, M. (2003). Ngā kāhui pou launching Māori futures. Wellington, New Zealand: Huia.

Frankel, S. (2014). "Ka Mate Ka Mate" and the protection of traditional knowledge. In R. Dreyfuss \& J. Ginsburg (Eds.), Intellectual property at the edge: The contested contours of IP (pp.193-214). Cambridge, England: Cambridge University Press. http://doi.org/cvb5

Gardiner, W. (2007). Haka: A living tradition. Auckland, New Zealand: Hodder Moa.

Grainger, A. D., Newman, J. I., \& Andrews, D. L. (2005). Global Adidas: Sport, celebrity and the marketing of difference. In J. Amis \& T. B. Cornwall (Eds.), Global sport sponsorship (pp. 89-105). Oxford, England: Berg.

Gunsorknives. (2016). Heineken-RWC 2015: Mission, weapon, impact. Retrieved from http:// www.gunsorknives.ie/work/heineken-rugby -world-cup-2015

Hakarena. (2015, September 17). Retrieved from https://www.thetimes.co.uk

Hippolite, H. R., \& Bruce, T. (2014). Towards cultural competence: How incorporating Māori values could benefit New Zealand sport. In C. Hallinan $\&$ B. Judd (Eds.), Native games: Indigenous peoples and sports in the post-colonial world (pp. 85-106). Bingley, England: Emerald Group.

Hoeber, L., \& Shaw, S. (2017). Contemporary qualitative research methods in sport management. Sport Management Review, 20(1), 4-7. http:// doi.org/f9t9kv

Horne, J., Tomlinson, A., Whannel, G., \& Woodward, K. (2012). Understanding sport: A socio-cultural analysis. Abingdon, England: Routledge.

Jackson, S. J., \& Andrews, D. L. (Eds.). (2005). Sport, culture and advertising: Identities, commodities and the politics of representation. London, England: Routledge. http://doi.org/fqtmr2 
Jackson, S. J., Batty, R., \& Scherer, J. (2001). Transnational sport marketing at the global/ local nexus: The Adidas-ification of the New Zealand All Blacks. International Journal of Sports Marketing and Sponsorship, 3(2), 55-71. http://doi.org/cvb6

Jackson, S. J., \& Hokowhitu, B. (2002). Sport, tribes, and technology: The New Zealand All Blacks haka and the politics of identity. Journal of Sport \& Social Issues, 26(2), 125-139. http://doi.org/ dkmhr4

Johnson, T. (2014). Legends in black: New Zealand rugby greats on why we win. Auckland, New Zealand: Penguin.

Johnson, T., Martin, A. J., Palmer, F. R., Watson, G., \& Ramsey, P. L. (2013). Artefacts and the All Blacks: Rites, rituals, symbols and stories. Sporting Traditions, 30(1), 43-59.

Johnson, T., Martin, A. J., Palmer, F. R., Watson, G., \& Ramsey, P. L. (2014). A core value of pride in winning: The All Blacks' team culture and legacy. International Journal of Sport \& Society, 4(1), 1-14. http://doi.org/cvb7

Kāretu, T. (1993). Haka: The dance of a noble people. Auckland, New Zealand: Reed.

Kenny, K. (2015, September 24). Heineken the latest company to mock the haka for profits. Stuff. Retrieved from https://www.stuff.co.nz

Kuroda, Y., Geisler, G., Morel, P. C. H., \& Hapeta, J. (2017). Stress, emotions, and motivational states among traditional dancers in New Zealand and Japan. Psychological Reports, 120(5), 895-13. http://doi.org/f98xdh

Lee, J. (2005, June). Māori cultural regeneration: Pūrākau as pedagogy. Paper presented at the Centre for Research in Lifelong Learning International Conference, Stirling, Scotland.

Lee, J. (2009). Decolonising Māori narratives: Pūrākau as a method. MAI Review, 2(3), 1-12.

Mabire, J. (Producer). (2016, January 4). One News (6pm Primetime). Auckland, New Zealand: TVNZ Television Licensing.

McKay, J., \& Miller, T. (1991). From old boys to men and women of the corporation: The Americanization and commodification of Australian sport. Sociology of Sport Journal, 8(1), 86-94. http://doi.org/cvb8

Mead, H. M. (2016). Tikanga Māori: Living by Māori values (Rev. ed.). Wellington, New Zealand: Huia.

Ministry of Business, Innovation and Employment. (2014). Haka Ka Mate Attribution Act 2014 guidelines. Wellington, New Zealand: Author.
Muriwai, E., Houkamau, C. A., \& Sibley, C. (2015). Culture as cure? The protective function of Māori cultural efficacy on psychological distress. New Zealand Journal of Psychology, 44(2), 14-24.

Olsen, Y. H. (2015). Whiti te rā! Does the haka Ka Mate Attribution Act 2014 signify a step into the light for the protection of Māori cultural expressions? (Unpublished LLB[Hons] dissertation). University of Otago, Dunedin, New Zealand.

Pihama, L., \& Southey, K. (Eds.). (2015). Kaupapa rangahau: A reader $-A$ collection of readings from the Kaupapa Māori Research workshops series. Hamilton, New Zealand: Te Kotahi Research Institute.

Pihama, L., Tipene, J., \& Skipper, H. (2014). Ngā hua a tāne rore: The benefits of kapa haka-Scoping the research needs and options for developing a better understanding of the contribution that kapa haka makes to Aotearoa New Zealand society. Wellington, New Zealand: Manatū Taonga-Ministry for Cultural Heritage.

Reid, N. (2000, June 11). \$1.5m for haka. Sunday News, p. 1.

Royal, C. (1998). Te ao mārama: A research paradigm. In Te Pūmanawa Hauora (Ed.), Proceedings of Te Oru Rangahau Māori Research and Development Conference, School of Māori Studies, Massey University, 7-9 July 1998 (pp. 79-87). Palmerston North, New Zealand: Te Pūtahi-ā-Toi School of Māori Studies, Massey University.

Smith, G. H. (2000). Protecting and respecting indigenous knowledge. In M. Battiste (Ed.), Reclaiming indigenous voice and vision (pp. 209-224). Vancouver, Canada: UBC Press.

Smith, L. T. (1999). Decolonizing methodologies: Research and indigenous peoples. New York, NY: Zed Books.

Sparkes, A. C. (1995). Writing people: Reflections on the dual crises of representation and legitimation in qualitative inquiry. Quest, 47(2), 158-195. http://doi.org/cvb9

Stride, A., Fitzgerald, H. F., \& Allison, W. (2017). A narrative approach: The possibilities for sport management. Sport Management Review, 20(1), 33-42. http://doi.org/cvcb

Sturm, D. C., \& Lealand, G. (2012). Evoking “New Zealandness": Representations of nationalism during the 2011 (New Zealand) Rugby World Cup. New Zealand Journal of Media Studies, 13(2), 46-65. http://doi.org/cvcc

Te Kanawa, W. (2015, September 16). Ngāti Toa Rangatira insulted by Hakarena. Te Kaea. 
Retrieved from www.maoritelevision.com/news/ national/ngati-toa-rangatira-insulted-hakarena

Tuffery-Huria, L. (2016, March 23). Indigenous creative rights explored in Samoa. Radio New Zealand. Retrieved from http://www.radionz .co.nz/international/pacific-news/299704/ indigenous-creative-rights-explored-in-samoa

Waitangi Tribunal. (2011). Ko Aotearoa tēnei: A report into claims concerning New Zealand law and policy affecting Māori culture and identity. Te taumata tuatahi. Wellington, New Zealand: Legislation Direct.

Wi Neera, T. A. (2009, February 23). Haka may carry a price tag. New York Times. Retrieved from http://www.nytimes.com 